\title{
Articles
}

\section{Change in ESL Graduate Students' Perspectives on Non-Native English-Speaker Teachers}

\section{Gulbahar H. Beckett and Andrea Stiefvater}

This article discusses the findings of an ethnographic study that explored the perceptions of ESL graduate students toward non-native English-Speaker Teachers (NNESTs) in the United States, a little researched topic. Analysis of classroom observations and interviews with 12 ESL graduate students from various countries showed that international ESL graduate students were active agents capable of exercising their agencies in evaluations of NNESTs. Overall, students enjoyed having a non-native speaker as their ESL teacher, which suggests that NNESTs have the cultural capital necessary for teaching ESL center courses. The students also reported initial disappointment about the constraints of NNESTs and about their changed attitudes, which seemed to be connected to changes in their teachers' confidence and effectiveness in classroom management. Suggestions for further research and practice are made.

Cet article discute des résultats d'une étude ethnographique portant sur un sujet qui n'a attiré que peu d'attention jusqu'à présent: les perceptions qu'ont les étudiants en ALS aux cycles supérieurs des enseignants n'ayant pas l'anglais comme langue maternelle (NNESTs) aux États-Unis. Selon l'analyse d'observations faites en salle de classe et des entrevues auprès de 12 étudiants en ALS aux cycles supérieurs provenant de divers pays, ces étudiants internationaux jouent un rôle actif et exercent leur volonté dans l'évaluation des NNESTs. Globalement, les étudiants appréciaient avoir comme enseignants en ALS des personnes dont l'anglais n'est pas la langue maternelle, permettant de conclure que les NNESTs ont le capital culturel nécessaire pour enseigner les cours d'ALS $d u$ centre. Les étudiants ont également fait part d'une déception initiale face aux contraintes des NNESTs et à leurs attitudes modifiées, qui semblaient liées aux changements sur les plans de la confiance et l'efficacité de la gestion de la classe de leur enseignant. Nous proposons des pistes pour la recherche à l'avenir et pour la pratique.

\section{Background}

The literature we reviewed includes work about non-native English-speaker intensive English programs and English as a second language center instruc- 
tors, community and college ESL instructors, and university professors. In this article we refer to all these as non-native English-speaker teachers (NNESTs). NNESTs have been discouraged from teaching in the English as a second language (ESL) field in North America and in the teaching English as a foreign language (EFL) field elsewhere based on the native-speaker fallacy (Canagrajah, 1999; Kamhi-Stein, 2004; Mahboob, 2004; Phillipson, 1992). For example, Mahboob, Uhrig, Newman, and Hartford's (2004) survey of 118 intensive English program (IEP) administrators in the United States showed that only 112 of 1,425 ESL teachers in their programs were NNESTs. Although the native-speaker fallacy does not hold up either linguistically or pedagogically (Canagarajah), administrators believe in it and justify their decisions by stating that students prefer to learn from native speakers (Mahboob; Guo \& Beckett, 2007). Despite TESOL position statements that strongly discourage discrimination against non-native English-speaker teachers (TESOL, 2006) and encourage the recognition and appreciation of all varieties of English (TESOL, 2008), advertisements like that below continue to appear (The Linguist List, 2008).
Job Location:
China
Rank or Title:
Teacher
Linguistic Field(s): Teaching English
Language Specialty: English
LL Issue:
19.1305
Date Posted:
16-Apr-2008
Job Description:
1. Native English speakers in USA, CA, UK, AU, NZ.
2. At least 18 years old
3. Inspiring and active capabilities
4. Candidate should provide us with relevant internship documents issued by his school.
5. Candidate will be assigned as required into higher educational schools, K12, or kindergartens.

Also, Amin (1999), Braine (1999), and Thomas (1999) believe that some newly arrived English-language learners naïvely buy into this fallacy. Some NNESTs who have written about their experience report feeling challenged, disrespected, and discriminated against by their native- and non-native speaker students despite their excellent academic records and qualifications and their high proficiency in English. These and other related issues have been discussed in a few articles (Brutt-Griffler \& Samimy, 1999) and several books (Braine; Kamhi-Stein, 2004; Llurda, 2005). Most of these works focus on NNESTs' reflections on how their students view them. Other works such as Belcher and Connor (2001) and $\mathrm{Li}$ and Beckett (2006) include 
autobiographical and reflective discussions of various issues that include students' perceptions of NNESTs.

Although the above-mentioned works shed some light on how teachers perceive students' beliefs about NNESTs, little is known about how students, both native- and non-native speakers of English, feel about being taught by NNESTs (Llurda, 2005; Mahboob, 2004). In fact Braine (2002), Brutt-Griffler and Samimy (1999), and Mahboob (2004) all call for studies that explore students' perceptions in varying contexts. Furthermore, although Mahoob suggests that students' attitudes change with time and exposure, we know of no study that shows when and why students' attitudes change. Understanding when and why students' attitudes change is important because it can be helpful in designing relevant curricula that better prepare future NNESTs, and it can have important implications for further research. In this article we discuss the findings of an ethnographic study that bridges these gaps and advances our knowledge of the topic by adding much-needed empirical data from sources and a site that have not been studied before. The purpose of the study was to explore the perceptions and experience of ESL graduate students of being taught by NNESTs. The research questions guiding the study were: (a) How do ESL graduate students perceive being taught by NNESTs? (b) From students' perspectives, what are the affordances and constraints, if any, of NNESTs? and (c) When and why do students' perceptions change? Answers to these questions provide insight into the perceptions of non-native English-speaker students, who are "ultimately the most affected by the native and non-native dichotomy" (Braine, 2004, p. 19). They help ESL graduate students in similar contexts and others in their understanding of how NNESTs are viewed by their peers and why. They also contribute to the knowledge of NNEST trainers and employers who are required to make informed decisions in their training and hiring practices.

\section{Literature Review}

NNESTs' reflections on their students' perceptions. Our review of the literature shows that three strands of studies on students' beliefs about NNESTs are emerging. One includes reflective reports by NNESTs who have taught in various English-language programs. Mostly reflective, but also sometimes empirical, these studies examined among other things issues related to nonnative speaker teachers' perceptions of being NNESTs (Amin, 1999; Asher, 2006; Braine, 2004; Guo, 2006; Li, 2006). A general theme that emerges from this body of work is that despite excellent academic records and qualifications, NNESTs experience prejudice and disrespect from both native- and non-native speaker students. For example, Asher, a knowledgeable and prolific scholar of East Indian origin, reported her authority as a professor being questioned when her native speaker US students challenged her request to revise their assignments. Asher interprets the challenge as her 
students' inability to recognize that a professor who was not US-born and who spoke English with an un-American accent could correct their English.

NNESTs also reported prejudice and disrespect from non-native Englishspeaking students. Braine (2004), a well-qualified English teacher with an excellent command of the language, stated that two ESL students enrolled in one of his classes in the US complained about his accent and requested transfers to classes taught by native-speakers. Immigrant ESL teacher participants in Amin's (1999) study in Canada indicated a belief that non-white speakers of English were assumed to be non-native speakers, especially if they spoke with accents, which branded these teachers as less competent. Guo and Li (2006) reported similar prejudices from non-native Englishspeaking students. Guo described feeling unappreciated by her Asian Canadian university students as a legitimate university instructor. These students dropped out of her classes although she had two master's degrees and a doctoral degree from a top university in the area in which she was instructing. $\mathrm{Li}$, a knowledgeable young professor and prolific scholar of Asian origin, reported feeling disrespected by her Asian ESL graduate students, who canceled meetings, did not complete tasks on time, and rudely interrupted her during discussions. This was in sharp contrast to what some of her white male colleagues told her about the same students. These professors told $\mathrm{Li}$ that they felt embarrassed by the excessive respect these students showed them (e.g., walking out of their offices backwards), and indicated that age and gender might also be contributing factors in students' perceptions of NNESTs.

Attitudes of non-native English-speaking students being trained to be teachers. A second strand in the literature includes reports by non-native Englishspeaking student teachers in training (Phillion, 2003; Samimy \& Brutt-Griffler, 1999). In their hybrid quantitative-qualitative study of 17 nonnative-speaking TESOL graduate students in the US, Brutt-Griffler and Samimy found that nearly $90 \%$ of the participants perceived a difference between Native English-speaker teachers (NESTs) and NNESTs. They perceived the former as informal, flexible, and versatile in their teaching approaches and fluent, accurate, authentic, and colloquial in their language use. They perceived the latter as being efficient, knowledgeable about students' backgrounds, and sensitive to their needs, and as being knowledgeable in psycholinguistics and capable of applying their knowledge in their teaching. Phillion conducted a study to explore the experiences of five female NNESTs as they tried to gain teaching certification in Canada. Through conversations, interviews, and examinations of journals kept by the women, Phillion found that her participants perceived their accented English as detrimental to attaining permanent teaching positions.

Although the findings of these studies enlighten us on the perceptions of non-native English-speaker students being trained to be teachers, they do not 
provide insight into the perceptions of non-native English-speaking students of ESL, who as Braine (2004) observed, experience the native and non-native dichotomy most acutely. This is a gap that Brutt-Griffler and Samimy (1999) and Braine $(2002,2004)$ called to our attention and that some emerging studies have partly bridged (Benke \& Medgyes, 2005; Cheung, 2002; Liang, 2002; Moussu, 2002; Mahboob, 2004), which we review below.

Attitudes of students taught by NNESTs and NESTs. We found only five studies on students' attitudes toward NNESTs and NESTs (Benke \& Medgyes, 2005; Cheung, 2002; Liang, 2002; Mahboob, 2004; Moussu, 2002). Moussu explored students' initial feelings and expectations when taught by a NNEST. Survey and interview data collected from 84 IEP students aged 17-21 from various countries and four non-native English-speaking teachers from Japan, Argentina, Ecuador, and Switzerland indicated that the student participants perceived learning from NNESTs positively from the beginning. For example, $79 \%$ expressed respect and admiration for their non-nativespeaking teachers. Time and exposure to NNESTs resulted in even more positive attitudes. Liang investigated students' attitudes toward NNESTs' accents and the features of these teachers' speech that contributed to the students' preference for teachers. Her analysis of data collected from 20 ESL students, five NNESTs, and one NEST through surveys and ratings of audiorecorded lectures revealed that students rated pronunciation/accent in teachers' speech as very important, but that such ratings did not result in negative attitudes toward NNESTs. Furthermore, preparedness, humor, qualifications, and professionalism inferred from teachers' speech seemed to play a role in students' preferences.

Mahboob (2004) studied ESL students' attitudes toward their teachers and the factors that influenced their perceptions. Analysis of data collected from 32 students of various first-language backgrounds enrolled in a Midwestern US university intensive English program showed that participants perceived NESTs as more competent with English and better at teaching oral skills such as pronunciation and speaking, as well as vocabulary and culture. They perceived NNESTs as having more metalinguistic and cultural awareness, as being empathetic, and as good at teaching reading, writing, grammar, and language-learning skills. They also perceived NNESTs as more efficient because they were aware of ESL students' needs. Cheung (2002) investigated the attitudes of university students and teachers toward NESTs and NNESTs and their perceptions of their strengths and weaknesses. Data from a survey of 420 undergraduate students majoring in various subjects and from interviews with 10 students from three universities and 22 mostly expatriate English teachers from six universities in Hong Kong suggested that both students and teachers believed that NESTs and NNESTs had different strengths. They thought of the former as having high proficiency in English, which they were capable of using functionally, and as being knowl- 
edgeable about the cultures of the countries where English is spoken. The participants reported believing that the latter were empathetic to second-language learners' needs and knowledgeable of students' cultures and of English grammar.

Findings from a more recent study confirmed the findings of the research reviewed above. Benke and Medgyes (2005) surveyed 422 Hungarian students to explore ESL/EFL learners' judgments of NEST and NNEST characteristics and teaching behaviors. Results of the study indicated that participants showed no bias against NNESTs. They judged NNESTs to be just as capable, equally patient, but also "more demanding, thorough and traditional in the classroom than their native speaker colleagues, who are more outgoing, casual and talkative" (p. 204). Participants believed that NNESTs were better at explaining grammar, vocabulary, and translation, and that NESTs were better at pronunciation and at using colorful language.

The above review suggests that teachers, professors, and administrators may be overly sensitive when it comes to how students perceive NNESTs. That is, all the reflections of teachers and professors reviewed here indicate anticipation of discrimination, prejudice, disrespect, and underappreciation by students; yet the studies of students' perceptions of their NNESTs paint a much more positive picture, with no perception that NESTs are superior to NNESTs and no preference for NESTs in general, although there is a clear indication that some students believe that NESTs are better, particularly in some aspects of English such as pronunciation and idiomatic expression. This suggests that students may see NESTs and NNESTs as having unique, important, and complementary attributes that are essential for successful teaching, but that they may discriminate against their NNESTs (Amin, 1999; Asher, 2006; Braine, 2004; Guo; 2006; Li, 2006) by buying into the nativespeaker fallacy (Phillipson, 1992) that is used against NNESTs in the hiring of ESL teachers (Guo; Mahboob et al., 2004). Furthermore, the literature review suggests a need for further studies of students' - both native and non-native speakers of English-perceptions of NNESTs and of perception changes in various contexts (Braine, 2002, Brutt-Griffler \& Samimy, 1999; Llurda, 2005; Mahboob, 2004). However, we know of no study that shows when and why students' attitudes change. We conducted this study to bridge these gaps. The findings are important because they can be helpful in designing relevant curricula that better prepare future NNESTs and can have important implications for further research.

\section{Methodology}

This ethnographic study explored 12 ESL graduate students' experiences and perceptions of being taught by a NNEST in order to gain a deep understanding of the issues under investigation (Patton, 2002; Spradley, 1980). A total of 15 students participated in the study, but three students in the winter quarter 
interview only back-channeled or indicated agreement with nods. Thus there were 12 active participants in this study. See Table 1 for details. The students were aged 25-35 at the time of the study. A purposeful sampling procedure was used for site and participant selection in the belief that this would offer the most in-depth insight into the cultural phenomena being studied (Patton).

\section{Research Site, Participants, and Data Sources}

Data for the study were collected at a large Midwestern US university over two academic quarters (fall and winter) and focused on a course called Academic Presentation Skills, which was offered at the university ESL center and taught by a NNEST teaching assistant (hereafter referred to as the teacher), Madeline (pseudonym) from Mongolia, 30 years old. Madeline was beginning a doctoral program in teaching English as a second language (TESL) at the university. Each quarter, students who were enrolled in one section of the course were observed and interviewed. The choice of section was based on the second author's schedule. The students enrolled in the Academic Presentation Skills class were all ESL graduate students in various areas of study including engineering, medicine, arts and science, and business administration. The students in the fall class consisted of three women and six men. Of these nine students, eight were from the People's Republic of China (PRC), and one was from India. The winter quarter class was all male,

\section{Table 1}

Overview of Participants

\begin{tabular}{|c|c|c|c|c|}
\hline Pseudonym & Country of Origin & Gender & Program & Quarter Observed \\
\hline Samuel & India & $M$ & Art and Science & Fall \\
\hline Daisy & PRC & $\mathrm{F}$ & Engineering & Fall \\
\hline Lyndon & PRC & $M$ & Engineering & Fall \\
\hline John & PRC & $M$ & Medicine & Fall \\
\hline Denise & PRC & $\mathrm{F}$ & Business & Fall \\
\hline Smith & PRC & $M$ & Engineering & Fall \\
\hline Yvonne & PRC & $\mathrm{F}$ & Business & Fall \\
\hline Quentin & PRC & $M$ & Medicine & Fall \\
\hline Frank & PRC & $\mathrm{M}$ & Engineering & Fall \\
\hline Jeff & PRC & $M$ & Business & Winter \\
\hline Charles & India & $M$ & Engineering & Winter \\
\hline Jason* & India & $M$ & Engineering & Winter \\
\hline Tom ${ }^{*}$ & Egypt & $M$ & Medicine & Winter \\
\hline Phil & PRC & $M$ & Medicine & Winter \\
\hline Steve ${ }^{*}$ & Korea & $M$ & Arts and Science & Winter \\
\hline
\end{tabular}

*Interview responses not articulated. 
with two students from the PRC, one from Korea, two from India, and one from Egypt. Table 1 summarizes the information about the participants.

From the winter quarter, only the two students from China and one of the students from India spoke openly during the interview; the other students indicated agreement by nodding and/or orally indicating assent $(\mathrm{mmhmm})$ to the Chinese students' assertions. Because of their lack of articulated comments, these students' responses are not included in our findings.

Data were collected by the second author (hereafter referred to as the researcher), during the fall and winter quarters of the 2002-2003 academic year (October 2002 to March 2003) for a total of approximately six months and analyzed by both authors. Data sources consisted of audiotaped and field-noted classroom observations once a week for 18 weeks ( 27 hours total), one open-ended audiotaped interview with each student in the fall quarter, a group interview in the winter quarter, background information questionnaires completed by each student, interviews with the teacher, and documents (syllabi). Data were on students' perceptions of being taught by NNESTs and departmental policies on teaching international ESL graduate students as well as perceptions and practices of one NNEST in teaching ESL graduate students. However, the focus of this article is on students' perceptions of NNEST issues, so we discuss only the data that pertain to this focus.

The researcher was a "moderate" participant (Spradley, 1980, p. 60), attempting to maintain a balance between participation and observation. At times she fully participated in the class, especially when she was asked to do so by the teacher. At other times she remained an "outsider" (p. 57) to the class activities and focused solely on detailed observations. In this way the researcher was able to gain acceptance into the classroom, but also maintain a degree of introspection about class activities and interactions. The researcher is a Caucasian female native speaker of English from New York State. At the time of the data collection, she was a 28-year-old fellow doctoral student in the same cohort and a friend of Madeline. The students seem to have liked the researcher being in the class, which was indicated by the fact that they often chatted and laughed with her as well as asking her languageand non-language-related questions throughout her presence in their classes.

\section{Data Analysis}

Data were analyzed using Strauss and Corbin's (1998) grounded theory, a method of inductive analysis and creative synthesis (Patton, 2002) in which the researchers become immersed in the data in order to discover "important patterns, themes, and interrelationships" (p. 41). We followed the typical pattern of analysis in grounded theory as described by Strauss and Corbin by moving the analysis from open coding of general concepts to axial coding of related categories and subcategories created by the open coding. Specifically, while transcribing interviews and observation field notes, we noted a recur- 
ring theme of questions about the NNEST's accent; we broke the category into subcategories such as NNEST accent in classroom speech and in discipline-specific vocabulary; we then created relational statements about the phenomena identified through the coding process. Finally, we moved toward theory generation of the observed phenomena. Field notes and classroom observations were analyzed following Patton's suggestions for key issues and key events analysis, which allowed us to identify, refine, and theorize the categories and subcategories that we present and discuss below.

\section{Findings}

The findings of the study indicate that ESL graduate students are active agents capable of exercising their agencies in evaluations of NNESTs. Overall, the students enjoyed having a non-native speaker as their ESL teacher, suggesting that NNESTs have the cultural capital necessary for teaching ESL center courses. The students also reported initial disappointment about the constraints of NNESTs and then their changed attitudes, which seemed to be connected to changes in their teacher's confidence and effectiveness in classroom management.

Affordances of NNESTs: Content area courses. Students reported positive perceptions toward taking content-area courses from NNESTs in general, and ESL center courses in particular, seeing affordances in their teaching content courses such as presentation skills, business, mathematics, and engineering from them. The following excerpts from interviews with Smith (Chinese male) and others echo such sentiments.
Andrea: How do you feel about having non-native English speakers teaching you?
Smith: They are okay. My three teachers are non-native. Not American. I think so.
Andrea: What are they?
Smith: Don't know.
Andrea: What department?
Smith: Engineering.
Andrea: Indian professors?
Smith: Maybe. German and something else I think.
Andrea: How do you feel about it?
Smith: Okay. They speak different. Lot of accent. But, okay. It's about my field, engineering. So, it's okay.

Excerpt from an interview with Samuel (Indian male):

After I finish a couple of days I learn that this class is probably more presentation skills. That is, how to present effectively. Okay, so I said this is how we're taught. To be a native speaker I think is not important 
because that is not the pronunciation or nothing. The important thing is that I have to learn the presentation skills.

Excerpt from an interview with Lyndon (Chinese male):

Although Madeline is also a non-native teacher but she teach us how to make oral presentations and give us some practice, so I think it's not quite different from a native-speaker teacher.

Excerpt from an interview with John (Chinese male):

I think as a teacher, if she can give us some suggestions for the organization, for the presentation skills, and for ... for the platform. She can give us the suggestions, so I think she's fine.

These excerpts indicate that students approved of NNESTs, even those with accents, teaching content area courses such as engineering and presentation skills, but not for teaching pronunciation courses. For example, Smith had either an Indian or a German professor for his engineering courses, with which he seemed to have no problem. Samuel and Lyndon seemed to indicate being fine with Madeline, a NNEST, teaching them because she was also teaching a content course, oral presentation as opposed to an ESL course, pronunciation. This confirms the findings of Brutt-Griffler and Samimy (1999), Benke and Medgyes (2005), Cheung (2002), Liang (2002), and Mahboob (2004), where NNESTs were viewed in a similar light.

Students discussed other affordances of NNESTs, citing Madeline's experience as an international ESL person as beneficial to them, saying that as a non-native-speaker teacher, she could and did share her experiences and knowledge. John (Chinese male) expressed a view of Madeline summarizing such beliefs: "She's learning English, so she has some experience she can share with us." The following excerpts from interviews with Smith and Yvonne further illustrate this point.

Excerpt from an interview with Smith (Chinese male):

Advantage is that they [NNESTs] come from international students. They know what international students ... uh ... student background. They know the way how to improve their English. They know what should we improve.

Interview excerpt from Yvonne (Chinese female):

She [Madeline] not only taught about things in the book, she also taught us something else, about how you can study well, how you can prepare your study, some thing like that. She think ... a lot for us.

Analysis of the field notes and classroom observation data throughout the study suggested that Madeline demonstrated her knowledge of the subject matter and did indeed share her experience as an international ESL graduate 
student on numerous occasions. The following chat the before a November 17 class provided a concrete example.

Madeline: You don't look happy. Everything okay?

Smith: Yes. My professor not happy about me, my writing, I think. I think he doesn't like my writing, ESL, you know. I try, but it's not perfect. He doesn't tell me how I can make it perfect.

Madeline: Writing is hard for American students too. They say that. My professor said we can have native speakers proof-read before handing in the assignments. You tried that? It's helpful. I learn from it, you know, seeing how my writing is changed ... Next time, I can pay attention to some things and it gets better.

The March 12 class recording provided an additional example of Madeline sharing another strategy with two students who talked to her about challenges in participation in class discussion by telling them that they "have to start speaking, classmates and professors let you speak and listen. Otherwise, they move on and you never speak. They don't call you like the professors back home."

Students seemed to be pleased with how their classes went, with their interactions with Madeline, and with the various knowledge and strategies that she shared with them as an international ESL graduate student and a NNEST. These findings confirm the reports of Samimy and Brutt-Griffler (1999), Cheung (2002), Liang (2002), and Mahboob (2004) that students perceived NNESTs as empathetic and resourceful in sharing their learning experience and strategies. They also add to our knowledge by providing observational data with much-needed concrete examples of the sharing of survival skills and strategies.

Constraints of NNESTs. However, students were also candid when discussing their views regarding the constraints of NNESTs and expressing some disappointments, particularly early in the course, as early as the first class of the first quarter. They expressed views about NNESTs in general as well as their teacher Madeline in particular. All 12 of them said that ESL students should acquire native-like accents, which cannot be learned from NNESTs. Quentin (Chinese male) said,

Most international students, their pronunciation is not good. And we want something to improve on our pronunciation or their grammar and if their teacher is native spoken maybe is good to ask.

Quentin's sentiment was echoed by nine of the 12 students who admitted being initially disappointed at having a NNEST as their teacher because they wished to improve their spoken English fluency and thought that practicing by speaking to NESTs would help them reach this goal. The following 
excerpt from the interview with Frank (Chinese male) captures this sentiment.

Frank: I prefer American teacher.

Andrea: Why?

Frank: You know his English native. English is the teacher's native language should be better... In my department, I selected three courses. They are all non-native speakers.... In China, all of my teachers were not native speakers. I learned English for 13 years and I still can't speak fluent English. So I think it's not good method. Mm. The best way to know English is to practice, to talk to the native speaker.

Andrea: Do you have a lot of opportunity to do that?

Frank: No (laughs). You know, engineering, most students are non-native speakers.

This excerpt and other similar data imply that students wished to acquire native-like pronunciation and believed that only NESTs could help them achieve this goal. Such beliefs seem to be related to the fact that they had not had NESTs and native speaker peers with whom to practice English. Excerpts from the field notes show how such a view toward NNESTs was revealed in class during students' interactions with their teacher and with the second author. For example, in her October 24, 2002 field notes, the second author wrote,

A few things happened during this class which made me think that I'm regarded as an authority because I'm a NS. The first occurrence was actually not long into the class time. One of the students asked me [not their teacher] how to pronounce "Shawshank Redemption." I said it a couple of times for her, and she repeated it a few times.

Some students also reported having planned to learn native-speaker colloquial English and being disappointed at having a NNEST because they did not think a NNEST would be good at teaching it. These findings are similar to those of Asher (2006), conveying her feeling that her students did not trust her ability to judge the grammatical accuracy of English. An excerpt from an interview with Denise (Chinese female) captures this view.

Sometimes if I give a presentation I prepared, but maybe still not the real expression. And from the native-speaker we can learn this sentence we should express this way and another sentence that way.

Analysis of audiotaped classroom observation data revealed no constraints on the part of the teacher in explaining colloquial English. But it did reveal that Madeline, the teacher, spoke slightly accented English and sought help with the pronunciation of a few words. For example, the February 12, 2003 observations showed the second author helping Madeline with her 
pronunciation of the word mitosis, with which anyone, including native speakers of English, might have had difficulty, just as anyone might have an accent of some kind. It is possible that Madeline turned to the researcher for help or to double-check her pronunciation because she happened to be in the classroom and thought it was easier to ask the researcher rather than to look up the pronunciation of the word herself. Neither the field notes nor the audiotaped classroom observation data showed any sign of students being bothered by their teacher's pronunciation or her accent. It is also worth mentioning that although the students were candid about their initial disappointment about having a NNEST, none in this study dropped the classes or asked to transfer to another class, and no one appeared to have shown disrespect to the teacher, contrary to accounts by Braine (2004), Guo (2006), and $\mathrm{Li}$ (2006).

Change of perceptions. Various data imply a change of perceptions within the group and across groups and suggest that the changes in perception seemed to be related to a change in the teacher's confidence and classroom management. The first (fall) quarter, students shared their disappointment about having a NNEST, particularly at the beginning first quarter because they had hoped to have a NEST from whom they could learn not only presentation skills, but also oral English skills. They did not think they could do this with Madeline because her pronunciation might not be good, as indicated in this comment from Quentin (Chinese male) from an interview.

In the first class, I think that Madeline is very a good teacher, but she has not native pronunciation. And maybe her pronunciation is not very good. So we just learning from her and maybe something cannot improve very much.

An excerpt from an interview with Yvonne (Chinese female):

In the beginning of the course, I don't think it's a very good class.

Because what we hoped was to not only practice presentation skills, but also oral English. So what we hope is a native speaker to teach us about the presentation skills and also to practice oral English. So I think we are a little disappointed.

However, a change of perception occurred toward the end of the first quarter, as suggested by excerpts from interviews with Yvonne and Lyndon at the end of the first quarter.

In the beginning, I think she is not very experienced, not confident. So we thought perhaps she cannot teach us well. But Madeline is a good teacher. She's very responsible. I think she should speak more definitely. (Yvonne) 
Disappointing in the beginning. Her English is okay and she teach oral presentation, not pronunciation. But she ... emmm, not confident. She moved the class to a lot of places. Not sure with time. Sometimes when we discuss something, very hot topic, we can't stop. Everybody is very active. So that time maybe will lost a time control. Later she's okay. So that's good. (Lyndon)

The above excerpts illustrate that students initially (i.e., at the beginning of the first quarter) felt disappointed not only because they thought they could not learn all that they had hoped to learn in Madeline's class because she was a NNEST, but also because they thought that she appeared be unsure of herself and was having trouble with classroom management. But as pointed out by Yvonne and Lyndon in the above excerpts, they changed their opinion later because they discovered that she was a good and responsible teacher.

The group interviews conducted at the end of the second (winter) quarter confirmed such a change in perception. Three students who responded to the question about how they felt about being taught by NNESTs indicated that they were fine with it, especially when it was not a pronunciation course, and that Madeline was a good teacher who taught them what they needed to learn in an academic presentation skills course. Those who did not speak nodded in agreement. No one expressed disappointment, and only two of six students mentioned pronunciation as an issue compared with all nine students in the first quarter favoring NESTs for a pronunciation course, which was a clear change in perception.

Class observation data confirm that this change in perception might be closely related to a teacher's confidence and classroom management skills. For example, throughout the first quarter, Madeline appeared to be a knowledgeable and caring teacher who taught content knowledge and shared study skills with her students; however, she had some classroom management and confidence issues, especially at the beginning of the first quarter. She arrived in class on time, but never started teaching on time because she waited 5-10 minutes for late students. She seemed uncertain with her answers to students' inquiries about e-mail messages, replying with "Really? You didn't get my message. Let me check my Out-box" (sample excerpt from November 14 classroom observation data). In the fall quarter, none of the 36 individual short presentations (four presentations by each of the nine students) and a group debate finished on time, continuing for two to five minutes after the timer went off, with the teacher saying, "It's okay. Don't worry. Take your time" (sample excerpt from November 7 classroom observation data).

However, field notes and the audiotaped classroom data from the second quarter show a different Madeline: much more confident, efficient, and authoritative. All but three of the 24 short presentations (four presentations by each of the six students in class) and a group debate finished on time, with 
the teacher saying, "Your time is up. Just finish your sentence" (sample excerpt from January 22 class observation data) when the timer went off. Classes always started on time, and the teacher was sure of herself. In her January 14, 2003 field note, the second author wrote, "Madeline stated that she had sent an email to all students in the class, and one student claimed that he had not received it. Madeline replied by saying, 'Your email was there, so I'm sure I sent it."'

NNEST issue or novice NNEST issue? If the changes in Madeline's confidence and classroom management might have been possible contributors to the change in students' perceptions toward NNESTs, one may ask what really is at issue here. Is it a NNEST or a novice-NNEST issue, because confidence and classroom management problems can be something faced by any novice teacher, NESTs and NNESTs alike? Presenting data from the teacher's perspective is beyond the scope of this article. However, teacher interview data in another article on which we are working suggest that it may be an issue of a novice NNEST as well as one of dual identity. For example, Madeline's account confirmed students' accounts and the researchers' observation report that she appeared to have confidence and classroom management issues at the beginning of the first quarter. According to our forthcoming article, Madeline was nervous, unconfident, and distracted because of difficulties that she faced in her doctoral study because she was not able to participate in class discussions as she would have liked, which she attributed to her English not being "good enough to do academic stuff." She thought that the problems she had as a student negatively affected her teaching because she kept asking herself, "How can I teach in English if I have a problem studying in English?"

However, Madeline reported that she had "good reflection" toward the end of the first quarter and during the winter break about her studying and teaching. She discovered that engaging in academic discussions and critiquing readings were different from teaching an oral presentation skills course, and that she had fewer problems with the English language as a teacher than she did as a doctoral student. As a result, she decided to separate her student self from her teacher self and not to allow the difficulties she encountered in "doing academic stuff" to interfere with her teaching. According to Madeline, it was this realization and decision, plus what she had learned in her doctoral courses, that enabled her to become a more confident teacher. She elaborated on how the "Sociolinguistics and Teaching College ESL courses readings and articles Dr. B gave me, helped" and that she "read a book about native non-native speaker teachers," which changed her attitude about her thoughts about why she "can't be teaching in English" and helped her stop worrying about it. Also, according to our forthcoming article, Madeline became a more confident teacher toward the end of the first quarter, and she grew even more confident during the second quarter as she 
learned more about her responsibilities as a teacher. These changes in Madeline seemed to be related to the change in her students' perspectives toward NNESTs, another important point that adds to the NEST and NNEST discussion.

These findings are illuminating because they imply that NNESTs can be trained and that students may perceive trained and experienced NNESTs more positively than novice and inexperienced NNESTs. Madeline's assertion about the knowledge she gained on NEST and NNEST issues from her sociolinguistics and other course materials suggests that students' awareness about these issues may also be raised in order to help them understand the potential of NNESTs. These are important points that deserve discussion and further study.

\section{Discussion and Implications}

The findings of the current study suggest that NEST and NNEST issues are complex and that ESL graduate students are active and intelligent agents (Harré, 1993) capable of recognizing such complexity contextually (Beckett \& Stiefvater, 2006). Like the participants in the studies by Benke and Medgyes (2005), Brutt-Griffler and Samimy (1999), Cheung (2002), Liang (2002), and Mahboob (2004), the student participants in the current study believed that NNESTs could have much of the cultural capital necessary to maintain pedagogic authority (Bourdieu \& Passeron, 1977). They believed that their NNESTs in general, and Madeline in particular, were knowledgeable enough to teach them the content area knowledge that they needed, understood their needs, and shared survival and study skills with them. However, they also thought that there were constraints in having a NNEST, and they did not think that their teacher Madeline, or NNESTs in general, had some of the cultural capital (Bourdieu \& Passeron) that they thought was important in an ESL teacher: specific constraints-native accent, and ability to model colloquial speech-that confirmed Amin (1999), Braine (1999), Thomas (1999), Phillion (2003), Brutt-Griffler and Samimy, and Mahboob. This suggests that although ESL graduate students can see the affordances of NNESTs by acknowledging their cultural capital, they can also help perpetuate NEST superiority by insisting that NNESTs cannot teach pronunciation and colloquial English: the native-speaker fallacy (Phillipson, 1992) as discussed in Amin (1999), Asher (2006), and Braine (2004).

However, our findings also suggest that students' perceptions can change over time, as suggested by Mahboob (2004), especially when students notice positive changes in their teachers. For example, participants' perceptions in the current study changed when they noticed that their teacher had become more confident and managed her class better by exercising more authority, another example that speaks to students' ability to exercise their active agency (Harré, 1993). 
This is one of few studies on a topic that needs to be studied further in various contexts and from various angles. Therefore, we call for further research to be conducted in other contexts with other participants with varying foci or the same foci, but by other researchers. For example, future research might analyze classroom discourse to see what linguistic constraints, if any, exist in NNEST talk and to suggest strategies for a remedy. Dialogic studies could also be conducted in various contexts to examine the perceptions of NESTs and their non-native English-speaking students, and NNESTs and their native and non-native English-speaking students, to find out why they perceive each other as they do, so that conflicts, if any, might be addressed. Nevertheless, we believe that the findings of this study contribute to ESL/EFL education in general and to the discussion of students' perceptions of NESTs and NNESTs by adding much-needed empirical data provided by ESL graduate students from various disciplines. It extends the current discussion in the literature by showing how a student-perceived lack of linguistic cultural capital, that is, native pronunciation, expresses itself in real classroom situations and how, when, and why students' attitudes toward NNESTs change.

A few implications can be drawn from the study. International ESL students like the participants in this study should understand that although it is good to have native speakers as language teachers, this is not the only contributor to students' linguistic proficiency and acquisition of native-like pronunciation and colloquialism. They must realize that teachers alone, whether native or non-native, cannot work wonders in helping students acquire native-like accents and idiomatic expressions in 30 contact hours over a 10-week quarter (the situation in which the participants in the current study were, which is common across North America). They must understand that the process also involves students' aptitude and commitment to learning a language and resourcefulness in seeking assistance from all available sources such as their ESL program, families, communities, and larger societies. Only then can native-like accents and idiomatic expressions be acquired. They should also understand that the ideal native speaker as defined by Chomsky (1965) may not exist (Braine, 2004) and that the prized capital of native-like proficiency in English is achievable through social interaction and education (Kramsch (1997), which means that some NNESTs can teach pronunciation and idiomatic English. Such an understanding can by extension empower NNESTS, as in the case of Madeline in our study, who learned about NEST and NNEST issues in her doctoral program and became a better teacher.

Administrators and teachers' trainers can benefit because the findings of this study can also raise their awareness that many NNESTs do have nativelike proficiency-achieved through education and social interaction (Kramsch, 1997) — that they are knowledgeable and capable of teaching sub- 
ject matter content, and that they can be resourceful and empathetic teachers. Teacher training programs for TESL or TEFL can use the findings of this study to inform their practices by helping their NNESTs-in-training to understand how their ESL students may view them, what they may expect from them, and how they can prepare themselves by enhancing their self-confidence, effective classroom management skills, and professional authority while working on their pronunciation and idiomatic English if necessary.

\section{The Authors}

Gulbahar H. Beckett is an associate professor of sociolinguistics and applied linguistics in the University of Cincinnati. Her research includes project-based and content-based ESL/EFL and second- and minority-language policies. She has published widely in such journals as TESOL Quarterly, Modern Language Journal, the Canadian Modern Language Review, TESL Canada Journal, and ELT Journal. She has also published books that include Project-Based Second and Foreign Language Education: Past, Present, and Future, Information Age Publishing.

Andrea L. Stiefvater is an adjunct assistant professor in the University of Cincinnati and a faculty member in Mohawk Valley Community College, NY. Her research interests include second-language writing, language socialization, non-native-speaker teachers, and computer-assisted language-learning. She has presented at TESOL, AERA, and the Canadian Learned Society. She may be reached at a.stiefvater@gmail.com.

\section{References}

Amin, N. (1999). Minority women teachers of ESL: Negotiating white English. In G. Braine (Ed.), Non-native educators in English language teaching (pp. 93-104). Mahwah, NJ: Erlbaum.

Asher, N. (2006). Brown in black and white: On being a South Asian woman academic. In G. Li \& G.H. Beckett (Eds.), "Strangers" of the academy: Asian women scholars in higher education (pp. 163-177). Sterling, VA: Stylus, LLC.

Beckett, G.H., \& Stiefvater, A. (2006, March). Student perspectives on nonnative speaker teachers. Paper presented at the TESOL Annual Convention, Tampa, FL.

Belcher, D., \& Connor, U. (Eds.). (2001). Reflections on multiliterate lives. Clevedon, UK: Multilingual Matters.

Benke, E., \& Medgyes, P. (2005). Differences in teaching behavior between native and non-native speaker teachers: As seen by learners. In E. Llurda (Ed.), Non-native teachers: Perceptions, challenges, and contributions to the profession (pp. 195-215). New York: Springer.

Bourdieu, P., \& Passeron, J.C. (1977). Reproduction in education, society and culture. Thousand Oaks, CA: Sage.

Braine, G. (Ed.). (1999). Non-native educators in English language teaching. Mahwah, NJ: Erlbaum.

Braine, G. (2002). Academic literacy and the non-native speaker graduate student. Journal of English for Academic Purposes, 1(1), 59-68.

Braine, G. (2004). The nonnative English-speaking professionals' movement and its research foundations. In L.D. Kamhi-Stein (Ed.), Learning and teaching from experience: Perspectives on nonnative English speaking professionals (pp. 9-24). Ann Arbor, MI: University of Michigan Press.

Brutt-Griffler, J., \& Samimy, K. (1999). Revisiting the colonial in the postcolonial: Critical praxis for nonnative-English-speaking teachers in a TESOL program. TESOL Quarterly, 33, 413-431.

Canagarajah, S. (1999). Interrogating the "native speaker fallacy": Non-linguistic roots, non-pedagogical results. In G. Braine (Ed.), Non-native educators in English language teaching (pp. 77-92). Mahwah, NJ: Earlbaum. 
Cheung, Y.L. (2002). The attitude of university students in Hong Kong towards native and non-native teachers of English. Unpublished master's thesis, Chinese University of Hong Kong.

Chomsky, N. (1965). Aspects of the theory of syntax. Cambridge, MA: MIT Press.

Guo, Y. (2006). Between the worlds: Searching for a competent voice. In G. Li \& G.H. Beckett (Eds.), "Strangers" of the academy: Asian women scholars in higher education (pp. 211-232). Sterling, VA: Stylus.

Guo, Y., \& Beckett, G.H. (2007). The hegemony of English as a global language: Reclaiming local knowledge and culture in China. Convergence, 40(1-2), 117-132.

Harré, R. (1993). Social being (2nd ed.). Oxford, UK: Blackwell.

Kamhi-Stein, L.D. (Ed.). (2004). Learning and teaching from experience: Perspectives on non-native English speaking professionals. Ann Arbor, MI: University of Michigan Press.

Kramsch, C. (1997). The privilege of the nonnative speaker. PMLA, 112, 359-369.

Li, G. (2006). Navigating multiple roles and multiple discourses: A young Asian female scholar's reflection on supervising and teaching fellow Asian students. In G. Li \& G.H. Beckett (Eds.), "Strangers" of the academy: Asian women scholars in higher education (pp. 118-133). Sterling, VA: Stylus.

Li, G., \& Beckett, G.H. (Eds.). (2006). "Strangers" of the academy: Asian women scholars in higher education. Sterling, VA: Stylus.

Liang, K.Y. (2002). English as a second language (ESL) students' attitudes towards non-native English speaking teachers' accentedness. Unpublished master's thesis, California State University, Los Angeles.

Llurda, E. (2005). Looking at the perceptions, challenges, and contributions ... or the importance of being a non-native speaker. In E. Llurda (Ed.), Non-native teachers: Perceptions, challenges, and contributions to the field (pp. 1-9). New York: Springer.

Mahboob, A. (2004). Native or nonnative: What do students enrolled in an intensive English program think? In L. Kamhi-Stein (Ed.), Learning and teaching from experience: Perspectives on non-native English speaking professionals (pp. 121-147). Ann Arbor, MI: University of Michigan Press.

Mahboob, A., Uhrig, K., Newman, K.L., \& Hartford, B.S. (2004). Children of a lesser English: Status of non-native English speakers as college level English as a second language teachers in the United States. In L. Kamhi-Stein (Ed.), Learning and teaching from experience: Perspectives on non-native English speaking professionals (pp. 100-120). Ann Arbor, MI: University of Michigan Press.

Moussu, L. (2002). English as a second language students' reactions to non-native English speaker teachers. Unpublished master's thesis, Brigham Young University.

Patton, M.Q. (2002). Qualitative research and evaluation methods (3rd ed.). Thousand Oaks, CA: Sage.

Phillion, J. (2003). Obstacles to accessing the teaching profession for immigrant women. Multicultural Education 11(1), 41-45.

Phillipson, R. (1992). Linguistic imperialism. Oxford, UK: Oxford University Press.

Samimy, K., \& Brutt-Griffler, J. (1999). To be a native or nonnative speaker: Perceptions of "non-native" students in a graduate TESOL program. In G. Braine (Ed.), Non-native educators in English language teaching (pp. 127-144). Mahwah, NJ: Erlbaum.

Spradley, J.P. (1980). Participant observation. Fort Worth, TX: Harcourt.

Strauss, A.L., \& Corbin, J.M. (1998). Basics of qualitative research: Techniques and procedures for developing grounded theory (2nd ed.). Thousand Oaks, CA: Sage.

TESOL. (2006, March). Position statement against discrimination of nonnative speakers of English in the field of TESOL. Retrieved June 1, 2008, from:

http:/ /www.tesol.org/s_tesol/seccss.asp?CID=32\&DID=37

TESOL. (2008, April). Position statement on English as a global language. Retrieved June 1, 2008, from:http:/ / www.tesol.org/s_tesol/seccss.asp?CID=32\&DID=37 
The Linguist List. (2008, April 16). Job announcement: Teachers Employment Network: English and teaching English: Teacher, Teachers Employment Network, Beijing, China. Retrieved June 1, 2008, from:http:/ /linguistlist.org/jobs/get-jobs.cfm?JobID=53480\&SubID=175721

Thomas, J. (1999). Voices from the periphery: Non-native teachers and issues of credibility. In G. Braine (Ed.), Non-native educators in English language teaching (pp. 5-14). Mahwah, NJ: Erlbaum. 